\title{
Oxidation of Elemental Mercury by Active Species Generated From a Surface Dielectric Barrier Discharge Plasma Reactor
}

\author{
Jiu Tao An $\cdot$ Ke Feng Shang $\cdot$ Na Lu $\cdot$ Yu Ze Jiang • Tie Cheng Wang • \\ Jie Li $\cdot$ Yan Wu
}

Received: 7 August 2013/Accepted: 30 September 2013/Published online: 18 October 2013

(C) The Author(s) 2013. This article is published with open access at Springerlink.com

\begin{abstract}
A surface dielectric barrier discharge plasma reactor was employed to study $\mathrm{Hg}^{0}$ oxidation in coal-fired flue gas. The experimental results showed that $98 \%$ of $\mathrm{Hg}^{0}$ oxidation efficiency and $13.7 \mu \mathrm{g} \mathrm{kJ}^{-1}$ of energy yield were obtained under a specific energy density (SED) of $7.9 \mathrm{~J} \mathrm{~L}^{-1}$. Increasing SED was beneficial for $\mathrm{Hg}^{0}$ oxidation due to higher production of active species. Higher initial concentration resulted in lower $\mathrm{Hg}^{0}$ oxidation efficiency, but higher amount of $\mathrm{Hg}^{0}$ oxidation. Water vapor inhibited $\mathrm{Hg}^{0}$ oxidation because the generation of $\mathrm{O}_{3}$ was suppressed. The presence of $\mathrm{NO}$ remarkably restrained $\mathrm{Hg}^{0}$ oxidation, while $\mathrm{SO}_{2}$ showed little effect on $\mathrm{Hg}^{0}$ oxidation. Roles of active species in $\mathrm{Hg}^{0}$ oxidation were examined under different gas atmospheres $\left(\mathrm{O}_{2}\right.$ and air), indicating that $\mathrm{O}_{3}$ played an important role in $\mathrm{Hg}^{0}$ oxidation. Deposits on the internal surface of the reactor were analyzed by energy dispersive spectroscopy and the product was identified as $\mathrm{HgO}$.
\end{abstract}

Keywords Surface discharge plasma reactor - Active species $\cdot$ Elemental mercury $\cdot$ Mercury oxidation

\section{Introduction}

Mercury has been listed as a hazardous and toxic pollutant under Title III of the 1990 Clean Air Act Amendments (CAAA) in the United States because of its volatility, persistence and bioaccumulation as methylmercury in the environment and its neurological health impacts

\footnotetext{
J. T. An · K. F. Shang · N. Lu · T. C. Wang · J. Li ( $₫) \cdot$ Y. Wu Institute of Electrostatics and Special Power, Dalian University of Technology, Dalian 116024, People's Republic of China e-mail: lijie@dlut.edu.cn
}

J. T. An · K. F. Shang · N. Lu - T. C. Wang · J. Li · Y. Wu

Key Laboratory of Industrial Ecology and Environmental Engineering, Ministry of Education of the People's Republic of China, Dalian 116024, People's Republic of China 
[1]. Coal-fired power plants are the major anthropogenic mercury emission sources in China and the U.S. because of the huge coal consumption for power generation [2]. Mercury is presented in coal-fired flue gas as elemental mercury $\left(\mathrm{Hg}^{0}\right)$, oxidized mercury $\left(\mathrm{Hg}^{2+}\right)$ and particle-bound mercury $\left(\mathrm{Hg}^{\mathrm{p}}\right)$ [3]. As reported, different species of mercury have different physical and chemical properties [4]. $\mathrm{Hg}^{\mathrm{p}}$ can be captured by particulate matter (PM) control devices such as electrostatic precipitators (ESPs) and fabric filters (FF). $\mathrm{Hg}^{2+}$ is soluble in water and has the tendency to associate with PM. Hence, $\mathrm{Hg}^{2+}$ is relatively easy to be removed from flue gas using typical air pollution control devices (APCDs). $\mathrm{Hg}^{0}$, however, is hardly captured by APCDs due to high equilibrium vapor pressure and water insoluble [5]. Therefore, with consideration of the properties of $\mathrm{Hg}^{2+}, \mathrm{Hg}^{\mathrm{p}}$ and $\mathrm{Hg}^{\mathrm{O}}$, studies for the $\mathrm{Hg}^{\mathrm{O}}$ oxidation methods should be first considered. Injection of powder activated carbon (PAC) impregnated with certain chemicals (i.e., sulfur species) has been successfully applied for the control of mercury emissions from incineration [6]. However, some drawbacks constrain the application of mercury adsorption technology in coal-fired flue gas purification, which includes high cost and high carbon-to-mercury ratio (3,000:1-100000:1).

As effective oxidation technologies, the preoxidation of $\mathrm{Hg}^{0}$ to $\mathrm{Hg}^{2+}$ is necessary for the removal of $\mathrm{Hg}^{0}$ by combining the present typical APCDs. Among preoxidation technologies under development, advanced oxidation processes (AOPs) are receiving great emphasis on pollution control because of their ability to rapidly oxidize hazardous air pollutants [7, 8]. Among the AOPs, non-thermal discharge plasmas (NTPs), which generate a large number of chemical active species such as $\cdot \mathrm{O}$ and $\mathrm{O}_{3}$, have been developed as a new method applicable for processing waste gas $[9,10]$, the removal of volatile organic compounds (VOCs) [11, 12] and oxidizing $\mathrm{Hg}^{0}$ [13-17]. NTP processes are highly effective in producing free radicals to enhance the removal of hazardous air pollutants.

Dielectric barrier discharge (DBD), one of NTPs, has received the most extensive investigation due to its high removal efficiency and environmental compatibility. DBD can be divided into four types based on the reactor geometry: typical DBD, surface discharge, coplanar discharge, and packed-bed discharge [12]. Surface DBD (SDBD) plasma reactors (SDBDs) have aroused considerable interest because of its unique features and characteristics, for example, SDBDs are easily manufactured than other DBD reactor, and SDBDs result in a decrease in the breakdown voltages, and thus better energy efficiency is obtained [18]. Moreover, the flue gas resistance in SDBDs is much less than that in other DBD reactors due to its wider electrode gap in SDBDs when flue gas passes through DBD reactors. Up to now, some researchers mainly focused on the removal of VOCs at low concentration levels using SDBDs [19-21]. For example, Oda et al. studied decomposition of gaseous organic contaminants by surface discharge induced plasma chemical processing (SPCP) and removal rates of $95 \%$ for acetone and $100 \%$ for 2-propanol were obtained using a ceramic tube reactor with strip-like electrodes [19]. Seung-Min Oh et al. used a surface discharge plasma reactor (SDBD) packed with various zeolites and the toluene adsorbed in micropores was decomposed by active oxygen species generated in the plasma zone on the zeolite surface [21]. However, only Masuda et al. [22] studied the oxidation of $\mathrm{Hg}^{0}$ in simulated flue gas using SPCP, and the study demonstrated that SPCP was a feasible technology to oxidize $\mathrm{Hg}^{0}$ in the flue gas, but the important parameters in $\mathrm{Hg}^{0}$ oxidation should be further evaluated in detail.

The objective of the study is to evaluate $\mathrm{Hg}^{0}$ oxidation performance of SDBD, and the important parameters including energy input, $\mathrm{Hg}^{0}$ initial concentration, gas atmospheres, and flue gas components $\left(\mathrm{H}_{2} \mathrm{O}, \mathrm{NO}, \mathrm{SO}_{2}\right)$ were examined. In addition, the evolution of $\mathrm{Hg}^{0}, \mathrm{Hg}^{2+}$ and total $\mathrm{Hg}$ concentrations was investigated, and the $\mathrm{Hg}^{0}$ oxidation mechanisms were also identified. 


\section{Experimental Section}

\section{Experimental Setup}

The experimental setup designed (Fig. 1) for study of the $\mathrm{Hg}^{0}$ oxidation was composed of a continuous gas flow sample generation system, a SDBD and a gas sampling analysis and detection system. The SDBD was comprised of a quartz tube (o.d. of $15 \mathrm{~mm}$, i.d. of $12 \mathrm{~mm}$ and length of $260 \mathrm{~mm}$ ), the outside of which was closely wrapped with the silver paper to act as a grounded electrode (length $200 \mathrm{~mm}$ ). The high voltage electrode was a stainless steel wire coiled (diameter of $1 \mathrm{~mm}$ ) on the inside of the tube. An AC voltage $(50 \mathrm{~Hz})$ was applied to produce the discharge plasma, and the peak voltage was varied from 4 to $12 \mathrm{kV}$. The peak voltage and current were measured with an oscilloscope (Tektronix TDS2014) equipped with a voltage probe (Tektronix P6015A) and a current probe (Tektronix P6021). The typical voltage and current waveform obtained in the experiment was shown in Fig. 2. The voltage-charge (V-Q) Lissajous method $(\mathrm{C}=1 \mu \mathrm{F})$ was used to determine the discharge power $(\mathrm{W})$.

\section{Experimental Methods}

All the experiments were run at a constant gas flow rate of $4.5 \mathrm{~L} \mathrm{~min}^{-1}$ at room temperature. A Dynacal mercury permeation device (VICI Metronic, Inc. USA) was used to provide trace mercury vapor of desired $\mathrm{Hg}^{0}$ concentration. The permeation device was located at the bottom of a glass U-tube that was immersed in a temperature-controlled water bath. Water vapor was generated by an evaporator and introduced into the flue gas with the carrier of air. The humidity of flue gas was measured with a humidity tester (Rotronic HP22-A + HC2-HK40). A RA-915 + mercury analyzer (Lumex, RU) coupled with RP91 was employed to measure $\mathrm{Hg}^{0}$ concentration. The balance of mercury was conducted in accordance with the ASTM method of Ontario Hydro sampling (ASTM D6784-02) [23]. The ozone $\left(\mathrm{O}_{3}\right)$ concentrations in flue gas were measured by the iodometry method [24]. The deposited mercury species elements were determined by energy-dispersive X-ray spectroscopy (EDX, NORAN system).

The definition of $\mathrm{Hg}^{0}$ oxidation efficiency was as follows:

$$
\mathrm{Hg}^{0} \text { oxidation effciency }(\%)=\frac{\mathrm{Hg}_{\text {in }}^{0}-\mathrm{Hg}_{\text {out }}^{0}}{\mathrm{Hg}_{\text {in }}^{0}} \times 100
$$

where $\mathrm{Hg}_{\text {in }}^{0}$ and $\mathrm{Hg}_{\text {out }}^{0}$ are the concentrations of $\mathrm{Hg}^{0}\left(\mu \mathrm{g} \mathrm{m}^{-3}\right)$ measured at the outlet of plasma reactor without or with high voltage discharge, respectively.

The specific energy density (SED) and energy yield were calculated:

$$
\begin{gathered}
\text { Specific energy density }\left(\mathrm{J} \mathrm{L}^{-1}\right)=\frac{\text { Consumption power }\left(\mathrm{J} \mathrm{s}^{-1}\right)}{\text { Gas flow rate }\left(\mathrm{L} \mathrm{min} \mathrm{min}^{-1}\right)} \times 60\left(\mathrm{~s} \mathrm{~min}^{-1}\right) \\
\text { Energy yield }\left(\mu \mathrm{g} \mathrm{kJ}^{-1}\right)=\frac{\text { Gas flow rate }\left(\mathrm{L} \mathrm{s}^{-1}\right) \times\left(\mathrm{Hg}_{\text {in }}^{0}-\mathrm{Hg}_{\text {out }}^{0}\right)}{\text { Consumption power }\left(\mathrm{J} \mathrm{s}^{-1}\right)} .
\end{gathered}
$$




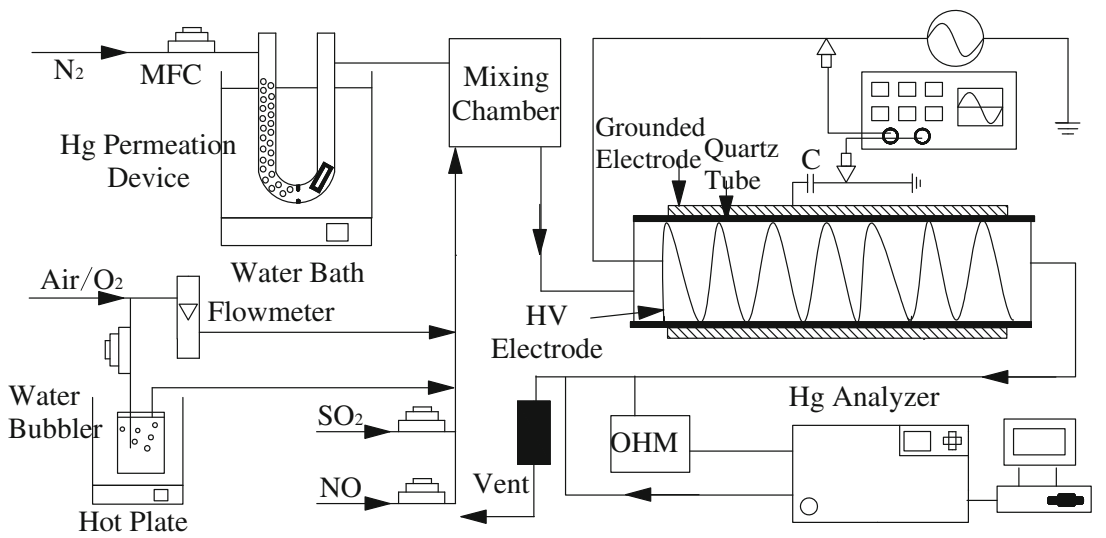

Fig. 1 Schematic diagram of the experimental system

Fig. 2 Typical voltage and current waveforms obtained $(12 \mathrm{kV})$

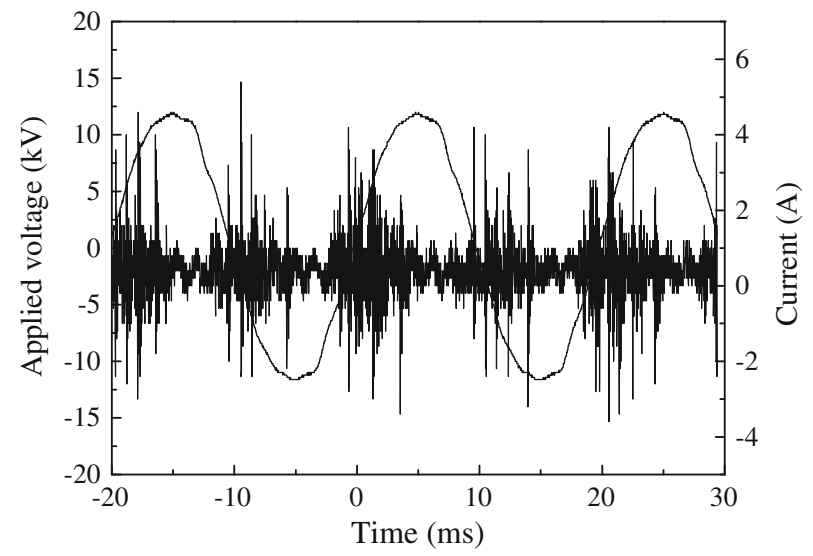

\section{Results and Discussion}

\section{Effect of Energy input on $\mathrm{Hg}^{0}$ Oxidation Efficiency}

The effect of energy input on $\mathrm{Hg}^{0}$ oxidation efficiency was illustrated in Fig. 3. Obviously, increasing SED enhanced $\mathrm{Hg}^{0}$ oxidation efficiency due to a higher energy input introduced in the discharge. With an increase of SED from 0.8 to $7.9 \mathrm{~J} \mathrm{~L}^{-1}, \mathrm{Hg}^{0}$ oxidation efficiency increased from 80 to $98 \%$. Increasing SED leads to the production of more plasma channels and chemically active species, therefore, $\mathrm{Hg}^{0}$ oxidation efficiency is enhanced. In addition, $\mathrm{Hg}^{0}$ oxidation efficiency of $80 \%$ achieved at SED of $0.8 \mathrm{~J} \mathrm{~L}^{-1}$, indicated that SDBD showed excellent performance of $\mathrm{Hg}^{0}$ oxidation.

$$
\begin{gathered}
\mathrm{e}+\mathrm{O}_{2} \rightarrow \cdot \mathrm{O}+\cdot \mathrm{O}+\mathrm{e} \\
\cdot \mathrm{O}+\mathrm{O}_{2}+\mathrm{M} \rightarrow \mathrm{O}_{3}+\mathrm{M} \\
\cdot \mathrm{O}+\mathrm{Hg}^{0} \rightarrow \mathrm{HgO} \\
\mathrm{O}_{3}+\mathrm{Hg}^{0} \rightarrow \mathrm{HgO}+\mathrm{O}_{2} .
\end{gathered}
$$


Fig. 3 Effect of energy input on $\mathrm{Hg}^{0}$ oxidation efficiency (conditions: $\mathrm{Hg}^{\mathrm{O}}$ initial concentration $100 \mathrm{\mu g} \mathrm{m}^{-3}$; dry air)

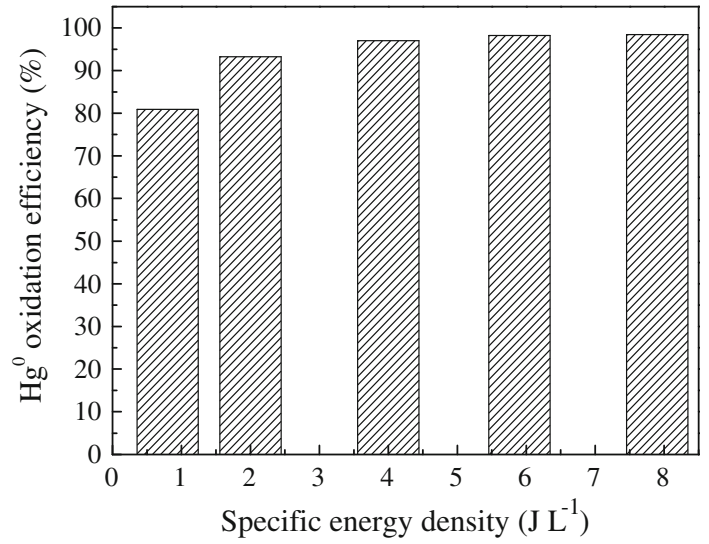

Table 1 Statement of experimental results obtained with different plasma reactors

\begin{tabular}{llcclcl}
\hline Reactor & $\begin{array}{l}\mathrm{Q} \\
\left(\mathrm{L} \mathrm{min}^{-1}\right)\end{array}$ & $\mathrm{Hg}_{\text {in }}^{0}\left(\mu \mathrm{g} \mathrm{m}^{-3}\right)$ & $\begin{array}{l}\mathrm{SED} \\
\left(\mathrm{J} \mathrm{L}^{-1}\right)\end{array}$ & $\begin{array}{l}\text { Oxidation } \\
\text { efficiency }(\%)\end{array}$ & $\begin{array}{l}\mathrm{EY} \\
\left(\mu \mathrm{g} \mathrm{kJ}^{-1}\right)\end{array}$ & Ref. \\
\hline CCDR & 2.5 & 300 & 23.7 & 59 & 7.5 & {$[13]$} \\
Wire-plate type & 2 & 50 & 18 & 80 & 2.2 & {$[25]$} \\
Wire-cylinder reactor & 6 & 110 & 894 & 98 & 0.1 & {$[26]$} \\
& & 80 & 98 & 1.3 & \\
$\mathrm{O}_{3}$ injection & 2.5 & 300 & 23.7 & 93 & 12.3 & {$[13]$} \\
$\mathrm{SDBD}$ & 4.5 & 110 & 7.9 & 98 & 13.7 & This study \\
\hline
\end{tabular}

In order to show performances of the SDBD compared to other types of plasma reactor, a brief comparison of the present results with other similar works was summarized in Table 1. Concentric cylinder discharge reactor (CCDR) and wire-plate type reactor exhibited lower $\mathrm{Hg}^{0}$ oxidation efficiency and energy yield compared with the present study. For example, $59 \%{\mathrm{of} \mathrm{Hg}^{0} \text { oxidation efficiency and } 7.5 \mu \mathrm{g} \mathrm{kJ}}^{-1}$ of energy yield was obtained for the CCDR [13], and $80 \%$ of $\mathrm{Hg}^{0}$ oxidation efficiency and $2.2 \mu \mathrm{g} \mathrm{kJ}^{-1}$ of energy yield was observed for the wire-plate type reactor [25]. $\mathrm{Hg}^{0}$ oxidation efficiencies obtained by the wire-cylinder reactor [26] were comparable with that of the present research, but the energy yields were much lower than that of the present study. For ozone injection technology [13], $\mathrm{Hg}^{0}$ oxidation efficiency and energy yield were comparable with that of the present research. For example, $93 \%$ of $\mathrm{Hg}^{0}$ oxidation efficiency and $12.3 \mu \mathrm{g} \mathrm{kJ}^{-1}$ of energy yield was obtained for the ozone injection technology [13]. Hence, it is believed that it is an alternative and efficient method for SDBD to oxidize $\mathrm{Hg}^{0}$ in the coal-fired flue gas. However, energy yield is strongly dependent on multiple factor, including air flow rate (Q), initial concentration and SED, for example, higher initial concentration and lower SED results in higher energy yield. Therefore, Table 1 gives only a qualitative and approximate comparison.

\section{Effect of $\mathrm{Hg}^{0}$ Initial Concentration on $\mathrm{Hg}^{0}$ Oxidation Efficiency}

Generally, $\mathrm{Hg}^{0}$ concentration of actual flue gas strongly varies. The effect of $\mathrm{Hg}^{0}$ initial concentration on its oxidation was studied in the range of $50-170 \mu \mathrm{g} \mathrm{m}^{-3}$, and $\mathrm{Hg}^{0}$ 
Fig. 4 Effect of $\mathrm{Hg}^{0}$ initial concentration on $\mathrm{Hg}^{0}$ oxidation efficiency (conditions: $\mathrm{Hg}^{0}$ initial concentration $50-170 \mu \mathrm{g} \mathrm{m}^{-3}$; dry air)

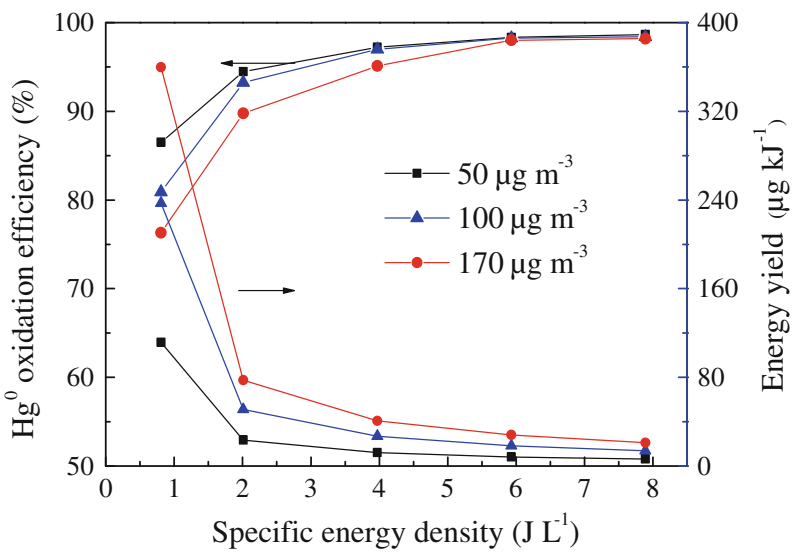

oxidation efficiency and energy yield were presented in Fig. 4. The results showed that $\mathrm{Hg}^{0}$ oxidation efficiency and energy yield were directly related to the initial concentration. $\mathrm{Hg}^{0}$ oxidation efficiency had a slight drop with the increase of $\mathrm{Hg}^{0}$ initial concentration from 50 to $170 \mu \mathrm{g} \mathrm{m}^{-3}$ at about $7.9 \mathrm{~J} \mathrm{~L}^{-1}$. However, energy yield remarkably enhanced from 6.3 to $21.1 \mu \mathrm{g} \mathrm{kJ}^{-1}$ under the same condition of SED. This phenomenon can be explained by the fact that the DBD energy dissipation levels remained comparable, the average energy availability per molecule decreased with the increase of the initial concentration. Hence, $\mathrm{Hg}^{0}$ oxidation efficiency decreased with an increase of the initial concentration. However, the absolute removal of $\mathrm{Hg}^{0}$ molecules increases because of higher initial concentration and higher probability of interaction with short-lived active species.

\section{Effect of Gas Atmospheres on $\mathrm{Hg}^{0}$ Oxidation Efficiency}

In order to investigate the roles of active species in $\mathrm{Hg}^{0}$ oxidation, experiments were conducted separately under oxygen and air atmospheres. The experimental results were shown in Fig. 5. As observed, $\mathrm{Hg}^{0}$ oxidation efficiencies under oxygen atmosphere were higher than that under air atmosphere. Under the condition of oxygen atmosphere, the density of oxygen-based active species produced in the discharge was larger than those under air atmosphere, resulting in higher oxidation efficiency in the case of oxygen atmosphere.

In order to study the contribution of $\mathrm{O}_{3}$ to $\mathrm{Hg}^{0}$ oxidation, the experiment of $\mathrm{Hg}^{0}$ oxidation by $\mathrm{O}_{3}$ treatment was conducted and the result was shown in Fig. 5. Herein, the $\mathrm{O}_{3}$ concentration was equal to that obtained by the discharge treatment under air atmosphere. $\mathrm{O}_{3}$ was generated by another of the same SDBD and injected into the reactor to react with $\mathrm{Hg}^{0}$. Under the condition of $0.8 \mathrm{~J} \mathrm{~L}^{-1}, 75 \%$ of $\mathrm{Hg}^{0}$ was oxidized, which was slightly lower than that under air atmosphere. These results indicated that (1) in the case of air atmosphere, there were other active species involved with the $\mathrm{Hg}^{0}$ oxidation in addition to $\mathrm{O}_{3}$. (2) $\mathrm{O}_{3}$ was the main active species for $\mathrm{Hg}^{0}$ oxidation.

\section{Effect of $\mathrm{H}_{2} \mathrm{O}$ on $\mathrm{Hg}^{0}$ Oxidation Efficiency}

The effect of $\mathrm{H}_{2} \mathrm{O}$ on $\mathrm{Hg}^{0}$ oxidation efficiency was presented in Fig. 6. At SED of $7.9 \mathrm{~J} \mathrm{~L}^{-1}$, compared with the dry gas, the addition of 3 and $5 \%$ water vapor dropped $\mathrm{Hg}^{0}$ 
Fig. 5 Effect of gas atmospheres on $\mathrm{Hg}^{0}$ oxidation efficiency (conditions: $\mathrm{Hg}^{\mathrm{O}}$ initial concentration $100 \mu \mathrm{g} \mathrm{m}^{-3}$ )

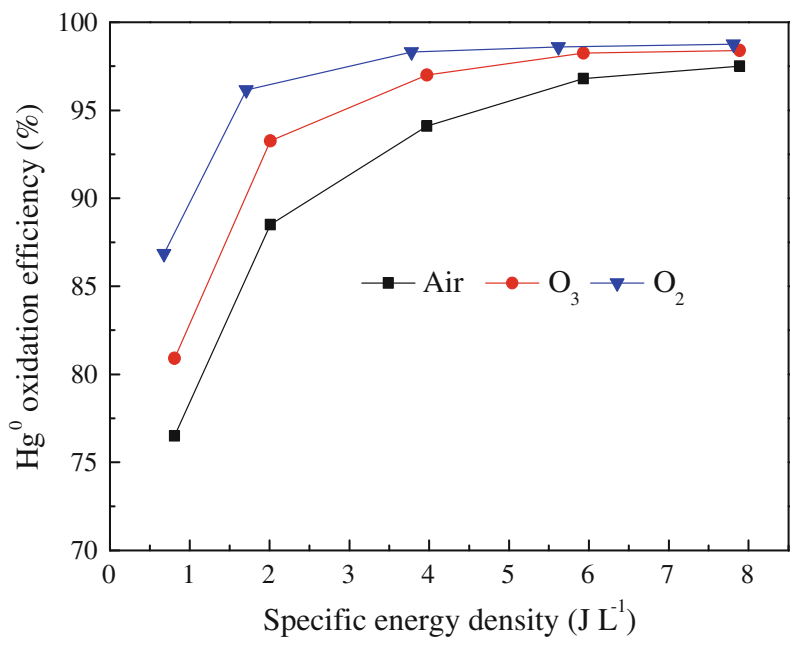

Fig. 6 Effect of $\mathrm{H}_{2} \mathrm{O}$ on $\mathrm{Hg}^{0}$ oxidation efficiency (conditions: $\mathrm{Hg}^{0}$ initial concentration $100 \mu \mathrm{g} \mathrm{m}^{-3}$ )

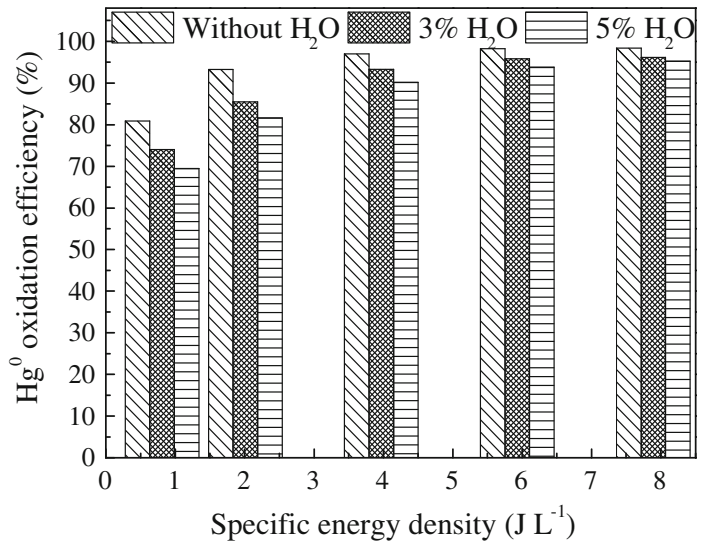

oxidation efficiency from 98 to 96 and $91 \%$, respectively. Therefore, the presence of $\mathrm{H}_{2} \mathrm{O}$ exhibited a slightly suppressed effect on $\mathrm{Hg}^{0}$ oxidation, and the similar result was reported by the literature [26]. $\mathrm{H}_{2} \mathrm{O}$ may react with $\mathrm{O}_{3}$ to form $\cdot \mathrm{OH}$, resulting in the decreasing of $\mathrm{Hg}^{0}$ oxidation efficiency due to the fact that the $\mathrm{O}_{3} / \cdot \mathrm{O}$ radicals are more effective than $\cdot \mathrm{OH}$ to oxidize $\mathrm{Hg}^{0}$. Simultaneously, $\cdot \mathrm{OH}$ can act as a promoter in the reactions (10) and (11) decreasing $\mathrm{O}_{3}$ and $\cdot \mathrm{O}$ [27-29]. As shown in Table 2, $\mathrm{O}_{3}$ concentration dropped with an increase of $\mathrm{H}_{2} \mathrm{O}$ contents, and higher $\mathrm{O}_{3}$ concentration was obtained for dry gas as compared to that for 3 and $5 \% \mathrm{H}_{2} \mathrm{O}$. Only $10.8 \mu \mathrm{g} \mathrm{L} \mathrm{L}^{-1}$ of $\mathrm{O}_{3}$ was observed for $5 \% \mathrm{H}_{2} \mathrm{O}$, whereas $\mathrm{O}_{3}$ concentration of $18 \mu \mathrm{g} \mathrm{L}^{-1}$ was obtained for dry gas at the same SED $7.9 \mathrm{~J} \mathrm{~L}^{-1}$. The reactions can be described as follows:

$$
\begin{gathered}
\mathrm{O}_{3}+\mathrm{H}_{2} \mathrm{O} \rightarrow \mathrm{H}_{2} \mathrm{O}_{2}+\mathrm{O}_{2} \\
\mathrm{H}_{2} \mathrm{O}_{2} \rightarrow \cdot \mathrm{OH}+\cdot \mathrm{OH} \\
\mathrm{O}_{3}+2 \cdot \mathrm{OH} \rightarrow 2 \mathrm{O}_{2}+\mathrm{H}_{2} \mathrm{O}
\end{gathered}
$$


Table $2 \mathrm{O}_{3}$ concentrations under different SED and $\mathrm{H}_{2} \mathrm{O}$ contents

\begin{tabular}{lccc}
\hline $\mathrm{SED}\left(\mathrm{J} \mathrm{L}^{-1}\right)$ & \multicolumn{3}{c}{$\mathrm{O}_{3}$ concentration $\left(\mu \mathrm{g} \mathrm{L}^{-1}\right)$} \\
\cline { 2 - 4 } & Without $\mathrm{H}_{2} \mathrm{O}$ & $3 \% \mathrm{H}_{2} \mathrm{O}$ & $5 \% \mathrm{H}_{2} \mathrm{O}$ \\
\hline 0.8 & 3.6 & 2.4 & 1.2 \\
2.0 & 6.7 & 5.8 & 3.3 \\
3.9 & 10.0 & 9.0 & 5.8 \\
5.9 & 14.2 & 11.8 & 7.4 \\
7.9 & 18.0 & 14.2 & 10.8 \\
\hline
\end{tabular}

Fig. 7 Effect of $\mathrm{NO}$ on $\mathrm{Hg}^{0}$ oxidation efficiency (conditions: $\mathrm{Hg}^{0}$ initial concentration $100 \mu \mathrm{g} \mathrm{m}^{-3}$; dry air)

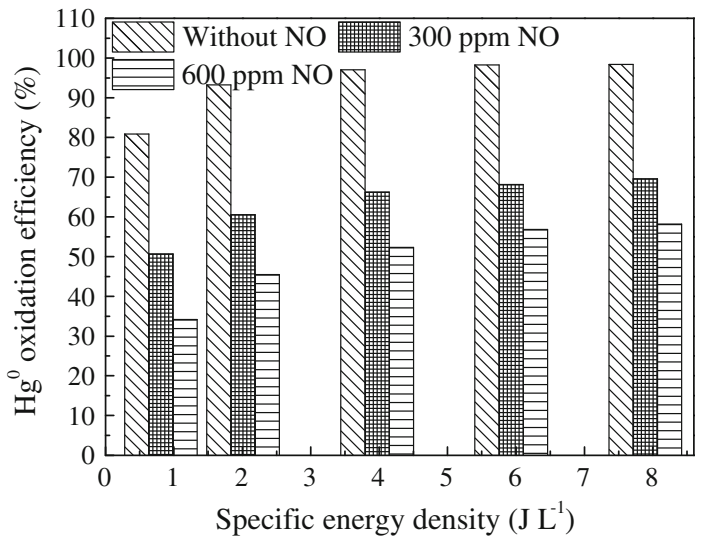

$$
\begin{aligned}
& \cdot \mathrm{OH}+\cdot \mathrm{O} \rightarrow \mathrm{O}_{2}+\cdot \mathrm{H} \\
& \cdot \mathrm{H}+\mathrm{O}_{3} \rightarrow \mathrm{O}_{2}+\cdot \mathrm{OH} .
\end{aligned}
$$

\section{Effect of $\mathrm{NO}$ on $\mathrm{Hg}^{0}$ Oxidation Efficiency}

NO is ubiquitous in flue gas environment and has significant impacts on $\mathrm{Hg}^{0}$ oxidation efficiency. As shown in Fig. 7, the presence of $\mathrm{NO}$ showed obvious inhibition on $\mathrm{Hg}^{0}$ oxidation. In the absence of $\mathrm{NO}, \mathrm{Hg}^{0}$ oxidation efficiency was $98 \%$ at around $7.9 \mathrm{~J} \mathrm{~L}^{-1}$, when NO concentration increased to $300 \mathrm{ppm}, \mathrm{Hg}^{0}$ oxidation efficiency had a dramatically decrease to $69 \%$, and with NO concentration increased to $600 \mathrm{ppm}, \mathrm{Hg}^{0}$ oxidation efficiency further dropped to $58 \%$ at the same SED. The competitive reactions of $\mathrm{Hg}^{0}$ and NO gases with the chemical active radicals generated in the reactor. The reaction rate coefficient of $\mathrm{NO}$ with $\mathrm{O}_{3}\left(1.8 \times 10^{-14} \mathrm{~cm}^{3}\right.$ molecules $\left.{ }^{-1} \mathrm{~s}^{-1}\right)$ (Reaction 13) [29] is much faster than that of $(10.5 \pm 0.65) \times 10^{-19} \mathrm{~cm}^{3}$ molecules ${ }^{-1} \mathrm{~s}^{-1}$ [30] for $\mathrm{Hg}^{0}$ reacting with $\mathrm{O}_{3}$, implying that the $\mathrm{O}_{3}$ can rapidly react with NO. Therefore, $\mathrm{O}_{3}$ will be preferentially exhausted, $\mathrm{Hg}^{0}$ oxidation efficiency markedly reduced, being in agreement with the results obtained in previous studies [31-33].

$$
\mathrm{NO}+\mathrm{O}_{3} \rightarrow \mathrm{NO}_{2}+\mathrm{O}_{2}
$$


Fig. 8 Effect of $\mathrm{SO}_{2}$ on $\mathrm{Hg}^{0}$ oxidation efficiency (conditions: $\mathrm{Hg}^{0}$ initial concentration $100 \mathrm{\mu g} \mathrm{m}^{-3}$; dry air)

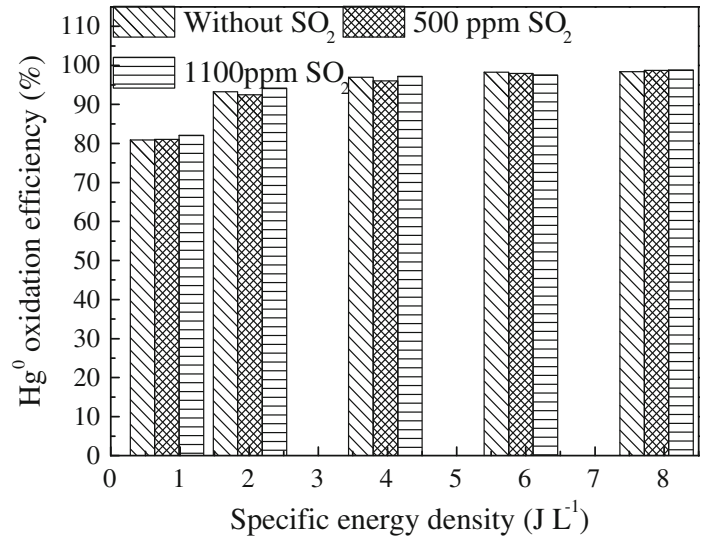

\section{Effect of $\mathrm{SO}_{2}$ on $\mathrm{Hg}^{0}$ Oxidation Efficiency}

The concentration of $\mathrm{SO}_{2}$ was varied to study effect of $\mathrm{SO}_{2}$ on the $\mathrm{Hg}^{0}$ oxidation (Fig. 8). As observed, no obvious decrease of $\mathrm{Hg}^{0}$ oxidation efficiency was detected when $500 \mathrm{ppm}$ $\mathrm{SO}_{2}$ was introduced to the gas flow or even when $\mathrm{SO}_{2}$ concentration further increased to $1100 \mathrm{ppm}$. The reason can be explained from the difference of the possible reaction mechanisms between $\mathrm{SO}_{2}$ and active species $\left(\cdot \mathrm{OH}, \cdot \mathrm{O}\right.$ and $\left.\mathrm{O}_{3}\right)$. As indicated in the previous research [28, 33], most $\mathrm{SO}_{2}$ is oxidized to $\mathrm{HSO}_{3}$ and $\mathrm{SO}_{3}$ by $\cdot \mathrm{OH}$ and $\cdot \mathrm{O}$ radicals which are the main radical species for oxidation due to the large rate constant compared with the other radical species such as $\mathrm{O}_{3}$. Therefore, the consumption of $\mathrm{O}_{3}$ by the reaction with $\mathrm{SO}_{2}$ is very minor. Additional, $\mathrm{Hg}^{0}$ and $\mathrm{O}_{3}\left((10.5 \pm 0.65) \times 10^{-19} \mathrm{~cm}^{3}\right.$ molecules ${ }^{-1} \mathrm{~s}^{-1}$ ) [30] reveal a relatively higher reaction rate constant than that of $\mathrm{SO}_{2}$ and $\mathrm{O}_{3}$ $\left(2.7 \times 10^{-23} \mathrm{~cm}^{3}\right.$ molecules $\left.{ }^{-1} \mathrm{~s}^{-1}\right)$ [34]. Therefore, it has been clearly demonstrated that $\mathrm{SO}_{2}$ shows little impact on $\mathrm{Hg}^{0}$ oxidation.

$$
\mathrm{SO}_{2}+\mathrm{O}_{3} \rightarrow \mathrm{SO}_{3}+\mathrm{O}_{2}
$$

The Mercury Mass Balance and Analysis of the Mercury Species Deposited on the Reactor Surface

The evolution of $\mathrm{Hg}^{0}, \mathrm{Hg}^{2+}$, and total $\mathrm{Hg}$ concentrations was shown in Fig. 9. With an increase of the SED, $\mathrm{Hg}^{0}$ concentration exhibited a dramatic decrease from 100 to $1.6 \mu \mathrm{g} \mathrm{m}^{-3}$, while the concentration of $\mathrm{Hg}^{2+}$ increased from 0 to $96.1 \mu \mathrm{g} \mathrm{m}^{-3}$, and then the total $\mathrm{Hg}$ concentration slightly decreased from 100 to $97.7 \mu \mathrm{g} \mathrm{m}^{-3}$ due to the reason that some mercury species in form of yellow deposits were accumulated on the internal surface of the reactor, presumably from the deposition of $\mathrm{HgO}$ formed through the oxidation of $\mathrm{Hg}^{0}$.

Energy dispersive spectroscopy (EDS) was used to determine the deposited mercury species elements and the measurement result was shown in Fig. 10. No Hg peak was detected at the blank sample and an $\mathrm{Hg}$ peak was detected for the inner surface of the reactor. Surface elemental composition of deposited mercury species in wt $\%$ and at.\% on the inner surface of the reactor were illustrated in Table 3. For the deposited mercury species, after excluding the composition of $\mathrm{SiO}_{2}$, the at.\% of $\mathrm{O}$ and $\mathrm{Hg}$ on the surface was 
Fig. 9 The typical mercury mass balance (conditions: $\mathrm{Hg}^{0}$ initial concentration $100 \mathrm{\mu g} \mathrm{m}^{-3}$; dry air)

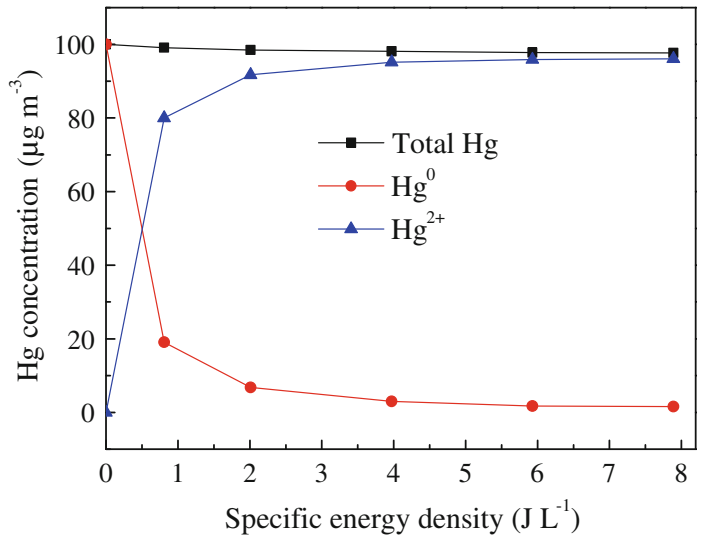

$\mathbf{a}$

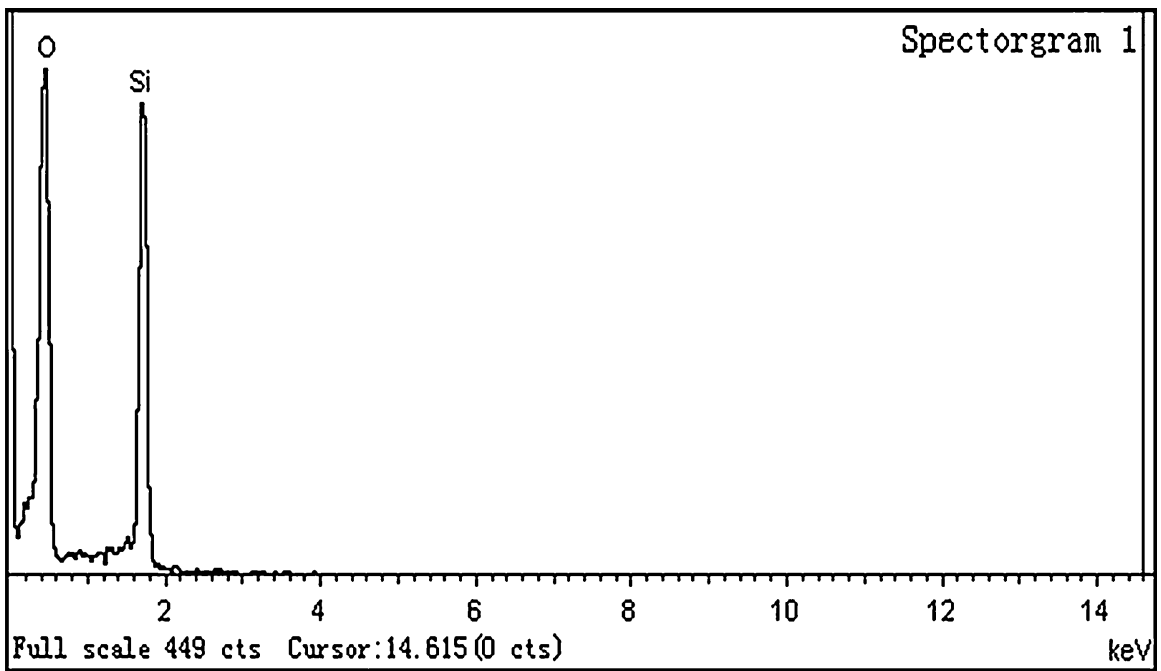

b

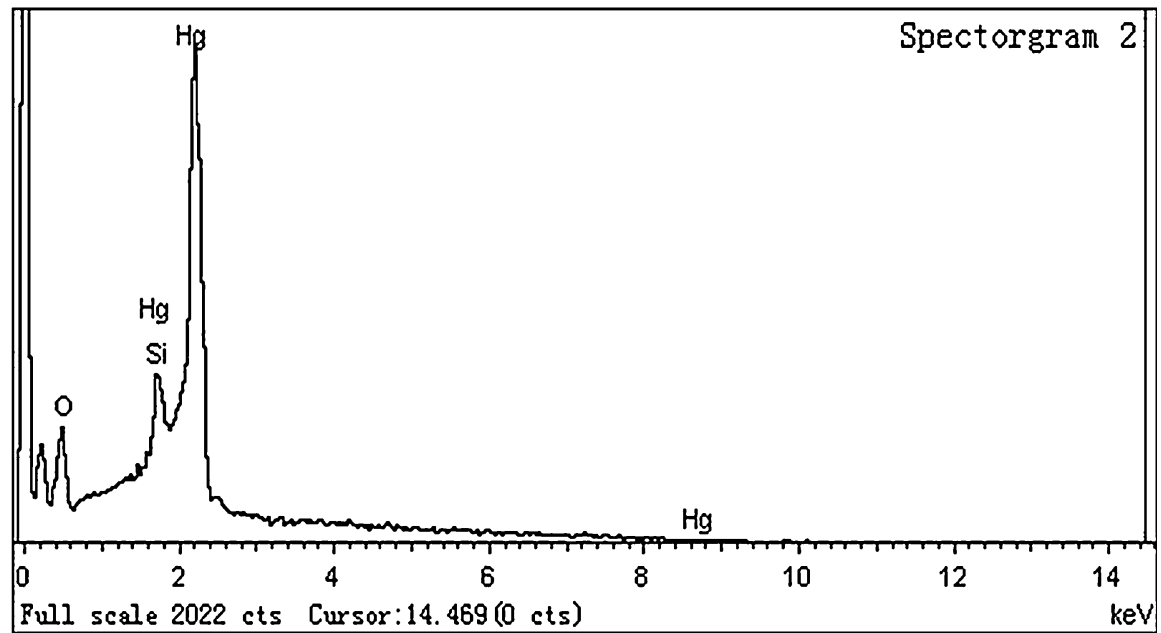

Fig. 10 EDS analysis of the reactor (quartz) surface a blank sample; b deposited mercury species 
Table 3 Surface elemental composition of deposited mercury species in wt $\%$ and at. \% on the reactor surface derived from EDS analyses

\begin{tabular}{lllllll}
\hline Samples & \multicolumn{2}{l}{ Blank sample } & & & \multicolumn{3}{l}{ Deposited mercury species } \\
\cline { 2 - 3 } \cline { 7 - 8 } & $\mathrm{Si}$ & $\mathrm{O}$ & & $\mathrm{Si}$ & $\mathrm{O}$ & $\mathrm{Hg}$ \\
\hline wt $(\%)$ & 46.85 & 53.15 & & 4.23 & 14.48 & 81.29 \\
at $(\%)$ & 32.78 & 67.22 & & 9.55 & 55.81 & 34.64 \\
\hline
\end{tabular}

observed to be approximately 36.71 and $34.64 \%$, implying that $\mathrm{Hg} / \mathrm{O}$ atomic ratio (1.05) of the sample was obtained. The results indicated that the deposited mercury species predominantly existed in the form of $\mathrm{HgO}$.

\section{Conclusions}

The application of SDBD for the oxidation of $\mathrm{Hg}^{0}$ in coal-fired flue gas was investigated in this study. High oxidation efficiency and energy yield of SDBD was obtained, which indicated that SDBD could be an alternative to other conventional technologies for efficient oxidation of $\mathrm{Hg}^{0}$. The investigation of contributions of active species to $\mathrm{Hg}^{0}$ oxidation indicated that $\mathrm{O}_{3}$ played a more important role during the treatment process. The deposited mercury species was monitored by EDS. Identified products were $\mathrm{HgO}$.

Acknowledgments The authors thank the National Natural Science Foundation, P.R. China (Project No. 51177007) and the Ministry of Science and Technology, P.R. China (Project No. 2009AA064101-4).

Open Access This article is distributed under the terms of the Creative Commons Attribution License which permits any use, distribution, and reproduction in any medium, provided the original author(s) and the source are credited.

\section{References}

1. Pavlish JH, Sondreal EA, Mann MD, Olson ES, Galbreath KC, Laudal DL, Benson SA (2003) Fuel Process Technol 82:89-165

2. Wu Y, Wang SX, Streets DG, Hao JM, Chan M, Jiang JK (2006) Environ Sci Technol 40:5312-5318

3. Kilgore JD, Sedman CB, Srivastava RK, Ryan JV, Lee CW, Thorneloe SA (2002) U.S. Government Printing Office Washington, DC

4. Wang YJ, Duan YF, Yang LG, Zhao CS, Shen XL, Zhang MY, Zhu YQ, Chen CH (2009) Fuel Process Technol 90:643-651

5. Scala F, Clack HL (2008) J Hazard Mater 152:616-623

6. Korpiel JA, Vidic RD (1997) Environ Sci Technol 31:2319-2325

7. Blanco MB, Bejan I, Barnes I, Wiesen P, Teruel AM (2012) Environ Sci Technol 46:8817-8825

8. Vandenbroucke AM, Morent R, Geyter ND, Leys C (2011) J Hazard Mater 195:30-54

9. Shang KF, Wu Y, Li J, Li GF, Li D, Wang NH (2006) Plasma Chem Plasma Process 26:443-454

10. Gutsol K, Nunnally T, Rabinovich A, Fridman A, Starikovskiy A, Gutsol A, Kemoun A (2012) Int J Hydrogen Energy 37:1335-1347

11. Wang HC, Li D, Wu Y, Li J, Li GF (2009) Journal of Electrostat 67:547-553

12. Pao CH, Chang SH, Chi KH, Chang MB (2010) J Hazard Mater 182:246-251

13. Byun Y, Ko KB, Cho M, Namkung W, Shin DN, Koh DJ, Kim KT (2008) Chemosphere 72:652-658

14. Ko KB, Byun Y, Cho M, Namkung W, Shin DN, Koh DJ, Kim KT (2008) Chemosphere 71:1674-1682

15. Chen Z, Mannava DP, Mathur VK (2006) Ind Eng Chem Res 45:6050-6055

16. Xu F, Luo Z, Cao W, Wang P, Wei B, Gao X, Fang MX, Cen KF (2009) J Environ Sci 21:328-332 
17. Yang HM, Liu H, Wu H, Wang M (2012) Plasma Chem Plasma Process 32:969-977

18. Malik MA, Kolb JF, Sun Y, Schoenbach KH (2011) J Hazard Mater 197:220-228

19. Oda T, Yamashita R, Takahashi T, Masuda S (1996) IEEE Trans Ind Appl 32:118-124

20. Ogata A, Kim HH, Shigeru F, Kushiyama S, Mizuno K (2004) Appl Catal B Environ 53:175-180

21. Oh SM, Kim HH, Ogata A, Hisahiro E, Shigeru F, Park DW (2005) Catal Lett 99:101-104

22. Masuda S, Hosokawa S, Tu X, Wang Z (1995) J Electrost 34(415):438

23. EPA. ASTMD6784202 (1999) Washington DC, EPA

24. Birdsall CM, Jenkins AC, Spadinger E (1952) Anal Chem 24:662-664

25. Byun Y, Koh DJ, Shin DN, Cho M, Namkung W (2011) Chemosphere 84:1285-1289

26. Wang MY, Zhu TL, Luo HJ, Wang H, Fan WY (2011) Ind Eng Chem Res 50:5914-5919

27. Seethamsetty S, Dhali SK, Dave B (2001) Appl Phys Lett 79:4298-4300

28. Ono R, Oda T (2003) J Appl Phys 93:5876-5882

29. Hilda MS, Marquidia PP, Joel OPS, Carlos ETR, Juan ADG (2007) IEEE Trans Plasma Sci 35:1533-1540

30. Rutter AP, Shakya KM, Lehr R, Schauer JJ, Griffin RJ (2012) Atmospheric Environ 59:86-92

31. Wang ZH, Jiang SD, Zhu YQ, Zhou JS, Zhou JH, Li ZS, Cen KF (2010) Fuel Process Technol 91:1395-1400

32. Ko KB, Byun Y, Cho M, Namkung W, Hamilton IP, Shin DN, Koh DJ, Kim KT (2008) Main Group Chem 7:191-204

33. Ko KB, Byun Y, Cho M, Namkung W, Hamilton IP, Shin DN, Koh DJ, Kim KT (2008) Appl. Phys. Lett. 92: 251503.1-251503.3.32

34. Atkinsonl R, Baulch DL, Cox RA, Crowley JN, Hampson RF, Hynes RG, Jenkin ME, Rossi MJ, Troe J (2004) Atmos Chem Phys 4:1461-1738 